\title{
THE ROLE OF FOREGROUNDING IN INTERPRETATION OF SUBTEXTUAL AND CONCEPTUAL INFORMATION IN A FICTIONAL TEXT
}

\author{
CMansurov R., ORCID: 0000-0001-5666-8374, Uzbek State University of World Languages, \\ Tashkent, Uzbekistan, Mansurovr92@gmail.com
}

\section{РОЛЬ ВЫДВИЖЕНИЯ В ИНТЕРПРЕТАЦИИ СУБТЕКСТУАЛЬНОЙ И КОНЦЕПТУАЛЬНОЙ ИНФОРМАЦИИ В ХУДОЖЕСТВЕННОМ ТЕКСТЕ}

\section{СМансуров Р. Д., ОRCID: 0000-0001-5666-8374, Узбекский государственный университет мировых языков, г. Ташкент, Узбекистан, Mansurovr92@gmail.com}

Abstract. One of the major issues in contemporary text linguistics is the analysis of the cognitive principles of distributing information in a literary text. Literary text unlike other types of the texts holds subtextual and conceptual information which could be encoded by the readers when they identify foregrounded parts of the text. Foregrounding is the type of cognitive principles of distributing information in the text and its main function is guiding the readers in interpretation of hidden and conceptual message of the text by showing some signals (important extracts) to the readers. In this article, the types and techniques of foregrounding are discussed, and their usages are observed in the short story The Luncheon by S. Maugham.

Аннотащия. Одним из основных вопросов современной лингвистики текста является анализ когнитивных принципов распространения информации в художественном тексте. Литературный текст, в отличие от других типов текстов, содержит субтекстовую и концептуальную информацию, которая может быть зашифрована читателями, когда они идентифицируют выдвижные части текста. Выдвижение - это тип когнитивных принципов распределения информации в тексте, и его основная функция заключается в том, чтобы направлять читателей в интерпретации скрытого и концептуального сообщения текста, показывая некоторые сигналы (важные экстракты) для читателей. В этой статье обсуждаются типы и приемы выдвижения, и их использование рассматривается в рассказе С. Моема «Завтрак».

Keywords: literary text, contextual information, subtextual information, foregrounding, coupling, convergence of stylistic devices, intertextuality.

Ключевые слова: художественный текст, контекстуальная информация, подтекстовая информация, выдвижение, сопряжение, конвергенция стилистических приемов, интертекстуальность.

One of the main problems of contemporary cognitive linguistics and text linguistics is the study of cognitive principles of distributing information in the text, in our case, in literary text. The necessity of examining these cognitive principles is actual because any text needs to be understood and interpreted. Foregrounding, being one of the prominent cognitive mechanism of distributing information in a text, assists the readers to find out the most important parts of any literary work and to interpret subtextual and contextual information that was sent by the writer. The term of 
foregrounding was initially described by the linguists of Russian Formal School and Prague linguistic circle [1]. To these days, the notion is widely used in modern linguistics, and the principle is being utilized by a vast number of writers while creating a piece of literature.

B. Gavranek and Ya. Mujarnovskiy (linguists of Prague linguistic circle) defined the concept of foregrounding on the basis of poetry. According to their ideas, in a poetic work, random misusage of literary norms is of the first importance as they help to catch the attention of the audience [2]. Over the past years, the term foregrounding was widely discussed by different schools of linguists and was given different definitions. Foregrounding is the concept that characterizes the importance of placing certain parts of a text or linguistic units at the first plan of text perception. These linguistic units or parts of the text are identified as a stimulus or a "key" in the process of linguistic and cognitive analysis of the text [3]. Foregrounding works as a guide in interpretation of conceptual information of a text. Furthermore, foregrounding activizes knowledge structures of a reader and helps to understand intentions, emotions and attitudes of an author towards a particular issue.

As it is widely known, informativity is the category of any kind of text. However, two types of information, subtextual and contextual, are mainly inherent to a fictional text. While interpreting the message of a literary work, one should perceive the conceptual information of it by analyzing both factual and subtextual information. At this place, defining a difference between the terms of subtextual and contextual is found to be necessary. According to D. Ashurova, subtextual information is an implicit information that could be studied by learning contextual meanings, additional senses, associative links, stylistic devices and expressive means. On the other hand, conceptual information is discrete one that reflects the author's conceptual world picture, his opinions about the people's social, political, financial and cultural life [1].

While learning the conceptual message of a fictional text, one should not limit with one or two analysis of stylistic devices or linguistic units. The analysis of a fictional text should be thorough and systematic embracing the whole text or a few important chunks of it. And in order to direct readers towards these important chunks, the writers use the mechanism of foregrounding besides other cognitive principles. There are several types of foregrounding that were mentioned by V. I. Arnold [3]: convergence, coupling, defeated expectancy and strong positions of a text. Descriptions of each style would be given further with plain examples for each type.

As a main analysis the short story of S. Maugham "The Luncheon" is going to be taken as an example followed by other pieces of literature also would be given in order to show the importance of foregrounding types. The plot of a story comprises the unsuccessful experience of a young and naïve writer with a very "experienced" in taking advantage of people's trustworthiness woman. In short, the story begins with a sudden meeting of two people who in past also once got acquainted in a luncheon. Several years ago, the antagonist of a story was asked for a modest luncheon by a middle-aged woman. He was a young writer without any serious experience in making appointments with women, so he had wrong expectations in terms of financial side of their modest luncheon. In the luncheon, the lady masterfully ordered the most expensive dishes and even did not pay a pence for her orderings. The poor writer, who could not dare to ask from her money, paid for everything and stayed in hunger the whole month. Let us analyze several parts of a text in terms of our issue.

Convergence of stylistic devices, in other words accumulation of expressive means of a language, in most cases urges readers to make more effort in comprehension of a given chunk of a text. In the text analyzed, there several cases of convergence. One of the most important parts of the story showing the usage of congergence is as follows: "The asparagus appeared. They were enormous, succulent and appetising. The smell of the melted butter tickled my nostrils as the 
nostrils of Jehovah were tickled by the burned offerings of the virtuous Semites. I watched the abandoned woman thrust them down her throat in large voluptuous mouthful and in my polite way I discoursed on the condition of the drama in the Balkans. At last she finished"[4]. Personification, epithet, allusion, hyperbole are used in order to reveal the inner state of the writer masterfully. The author, by using the intertextuality, tries to show dramatic condition of naïve writer. If we look into the first usage of intertextuality, we could reveal that according to the Bible, virtuous Semites were the ancient nation commanded by Noah son, and after each of their successful wars, they made offerings to the Jenovah. The wind of the nostrils of Jehovah, or of the Lord, denotes heaven, is because by it is meant the breath of life, thus the Divine life, and as this makes the life of heaven, by the wind of the nostrils of Jehovah is signified heaven. Here as we see, the author describes how the writer himself is hungry and how he also desires to eat such an appetizing and expensive meal that he almost compares it with divine offerings. "...I discoursed on the condition of the drama in the Balkans..." the second use of intertextuality shows the psychological state of the writer who waits for his fate to give him upcoming financial problems in his life. According to history, wars in Balkans were very long, turbulent and cruel as in our case, this condition of drama is compared with condition of waiting so long for the woman to have finished her orderings. As it is seen, from this extract of the text, readers could feel how unhappy and helpless the writer is and how smart and selfish the woman is.

Coupling, the second type of foregrounding, implies to any kind repetition of the language units throughout the text in order to show the importance of this very concepts that are coupled. Coupling is created by all types of repetition, parallel structures, synonyms, antonyms, words belonging to one and the same semantic field. Coupling can be expressed in different in length fragments of the text by means of linguistic units of all the language levels [1].

"Deep into that darkness peering, long I stood there wondering, fearing,

Doubting, dreaming dreams no mortal ever dared to dream before;

But the silence was unbroken, and the stillness gave no token,

And the only word there spoken was the whispered word, "Lenore?"...

This extract is taken from the poem "Raven" by E. A. Poe, the famous poem of the poet who illustrated his personal grief in his words. In the first two lines of the stanza, alliteration, the usage of the same sounds (-D) is utilized in order to show the irritation of the author by the silence and the unfinished grief and misfortune of losing his love. This example illustrates the usage of coupling at phonetic level. If we look into our major analysis, into the story "The Luncheon", we could also observe several cases of coupling. For instance, cunny woman at the beginning of meeting starts her orderings with the phrase "I never eat anything for luncheon" but after a while we could observe the phrase "I never eat more than one thing for luncheon", and so goes on the whole story with these parallel constructions. We dare to think that this type of coupling made deliberately by the author has its own important role as by these phrases we see how cunny and inconsistent character the woman has. By lying masterfully, she orders very expensive thing even not paying attention to the words of the young writer. This phrases also show that the woman is so selfish that she only repeats and starts her sentences with the word "I".

The next type of foregrounding is the method of putting important information to the strongest parts of the text. According to Arnold, the strongest parts of literary texts are the beginning and the ending of the text. To the beginning we could involve title, epigraph and first paragraph. Also, the importance of the ending of the text should be highlighted here. Some others intend to create work with open endings as they want the readers to create their own endings. In our case, the title of the text "the Luncheon" is itself ironical. In encyclopedic dictionaries, this type of 
eating time is considered to be very light consuming food, but as we observe, "the light snack" turns up as heavy, massive eating.

The last notion that is to be discussed is called "defeated expectancy" or in other words not suggested ending. This phenomenon is actually popular in the sphere of short story writing. S. Maugham also took advantage of this technique in the analyzed work. The last paragraph concludes with the sentences "....But I have had my revenge at last... To-day she weighs twenty-one stone”. Actually here, the writer used the last two techniques. Furthermore, by saying twenty one stone, he uses hyperbole in order to show how fat she has become. One more important thing to consider here is the sentence "....But I have had my revenge at last...". From this very sentence we can identify the author's conceptual world picture towards this issue. He wants to say that no bad action remains unanswered. When you someone takes advantage of the naiveness of other people, one day these people or the life itself takes revenge from them.

To summarize the above mentioned analysis, it should be entitled that every text should be comprehended and understood. In most cases, literary texts are developed by subtextual and contextual information that were used by the authors deliberately. In order to find out the message that these hidden pieces of information carry out, the readers need to be able to find foregrounded parts of the text. In the sample of the short story "the Luncheon" we tried to observe and analyze the cases of foregrounding and its types. So, while analyzing these techniques, we were more or less able to identify first pieces of subtextual, and then conceptual information of the work.

\section{References:}

1. Ashurova, D. U., \& Galieva, M. R. (2016). Text Linguistics. Tashkent: Turon-Iqbol,

2. Filippov, K. A. (2003). Lingvistika teksta. SPb.

3. Arnol'd, I. V. (2002). Stilistika. Sovremennyi angliiskii yazyk.

4. de Maupassant, G. (2019). Complete Short Stories. MVP.

\section{Список литературь:}

1. Ashurova D. U., Galieva M. R. Text Linguistics. Tashkent: Turon-Iqbol, 2016.

2. Филиппов К. А. Лингвистика текста. СПб., 2003.

3. Арнольд И. В. Стилистика. Современный Английский язык. М: Наука, 2002.

4. de Maupassant G. Complete Short Stories. MVP, 2019.

Работа поступила

в редакиию 09.03.2020 г.
Принята к публикациии

14.03.2020 2.

Ссылка для циитирования:

Mansurov R. The Role of Foregrounding in Interpretation of Subtextual and Conceptual Information in a Fictional Text // Бюллетень науки и практики. 2020. Т. 6. №4. С. 523-526. https://doi.org/10.33619/2414-2948/53/62

Cite as (APA):

Mansurov, R. (2020). The Role of Foregrounding in Interpretation of Subtextual and Conceptual Information in a Fictional Text. Bulletin of Science and Practice, 6(4), 523-526. https://doi.org/10.33619/2414-2948/53/62 